Available online at: http://proceeding.rsfpress.com/index.php/pss/index

LPPM UPN “Veteran” Yogyakarta Conference Series

Proceeding on Political and Social Science (PSS)

Volume 1 Number 1 (2020): 161-165

\title{
Zoom As A Tool For Online Learning
}

\author{
Indriati Retno Palupi, Wiji Raharjo \\ Universitas Pembangunan Nasional Veteran Yogyakarta \\ Email address Inder13101986@gmail.com
}

\begin{abstract}
There Change the design of the studying process in University during the covid-19 pandemic from face to face to online learning needs some tools to support it. Some tools coming with their own advantages and disadvantages. One of them is Zoom. It becoming tools liked by many lecturers and college students because easy installation process and complete features although it is not free and easy to hack. Nevertheless, internet access is still becoming a big problem in online learning. A mix between two tools of online learning is one of the solutions, for example, zoom and google classroom application. Zoom is used for virtual communication in online learning but it does not provide features for sending the assignment. Otherwise, google classroom provides features to send and receipt some assignments, and it can save the quote on the internet. Both of them will complete each other to support all needs in online learning.
\end{abstract}

Keywords: covid-19, online learning, zoom and google classroom

\section{INTRODUCTION}

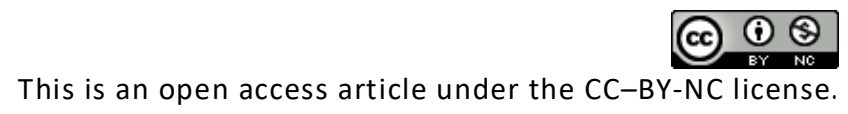

Coronavirus spreading started in the last 2019 in China than to the other country including in Indonesia changed human patterns and lifestyles. Almost all of the part in human activity is restricted and to prevent the massive spreading of coronavirus, Indonesia's Government publishes some regulation in Keppres No.12 2020. The regulation is known as a large scale of social distancing (PSBB).

PSBB effect felt much in the economy. No transaction in the market or shopping center makes some people's income decrease. In the education part, face to face learning on campus stopped because it worried to be a new source of coronavirus spreading. To handle the learning process, the education minister of Indonesia publish the regulation for online learning.

Although online learning can replace face to face learning on campus, the effect is not better than face to face learning. In face to face learning, the students can ask about the mastery of the lecturers directly. And the lecturers also can review the learning process by some method like giving some tests to the students suddenly. Besides that, the students still argue that face 
to face learning is more fun than online learning. In online learning, there is no interaction between the lecturers and the students and the students each other in the discussion group (Aji, 2020) so it needs some tools that cover all needs of face to the face learning process. The regulation of online learning in University is to be appointed in Panduan Pembelajaran Semester Gasal 2020/2021 di Perguruan Tinggi Edisi 1 Juni 2020. In that regulation, all campus activity is stopped include practice lessons, and changed by online learning except there is no choice as to if it is related to the graduation and done by notice healthy protocol. The purpose of this paper to describe the advantages and the weakness of each online learning tools like Zoom, Google Classroom, Google Meet, WA Group, and Email and then summarize what tools is the most popular in UPN "Veteran" Yogyakarta based on the students and the lecturer's opinion.

\section{RESEARCH METHODOLOGY}

Based on Rawan and Triwidiastuti, the method is a human's way to search for the answers to some questions of the various incident or natural phenomena. This paper is arranged by literation method to some references about online learning and do interview with random sample object in UPN "Veteran" Yogyakarta about the tools used in online learning.

The opinion of the quality of the online learning tools done by an interview with some students and the lecturers. The sampling technique is done using disproportionate stratified random because some factors like the students are limited. The respondents are the students in semester 4 or 5 because they are the biggest users in online learning include the practice lessons. The lecturers also as a subject of the interview. Some questions include what tools used for online learning, how about the cybersecurity of the tools, is it easy understanding or not, what the effect of the tools to the learning method, what is the difficulties as long as using the tools, and can the students do some work from the online learning tools.

The answers to the questions then calculated using the chi quadrat method. This is the statistic method to know some parameters like (Susilawati et al, 2017):

1. Know the relation between two variable

2. Know the homogeneity level of the sample

3. Normal test based on the distribution

4. Know the frequency to analyze the data

5. Know how the influence correlation between the variable

6. Useful for discrete data

The explanation about each parameter above is:

1. Variable si controlling condition or situation. The variable in this paper is the relation of the users (lecturers and the students) with the online learning tools. The relation can describe in the quantitative of qualitative categorize. In qualitative, the relation usually describes with the graph, while in quantitative the relation describe based on cause and effect between the variable.

2. The general definition of homogenous is the same. In this paper, homogenous is defined if the users have the same difficulties or not in the online learning process. 
3. The normal test is usually used to know the distribution of the data. The normal distribution is defined as the mean of the data. To solve it, prediction about the variable is needed and the result usually describe using the graph

4. Frequency defined as how many the variable appear. In this paper, it means how many online learning tools are used by users. The frequency used in this paper is to observe frequency. From the answers to the question, information about the tools can be known. Then what kind of tools are often used can be known too based on some reasons, one of them is the advantages and the weakness of each tool. For example, there is one tool that does not provide video call or virtual communication between the students and the lecturers but it provides to collect the assignment and not spend a lot of quotas.

5. The variable is usually very dynamic or not consistent. It is usually influenced by external factors. They are like an easy installation in various electronic media because some tools are not easy to installed in electronic media based on the memory or ram. Besides that, the external factor sometimes comes from the lecturers. The lecturers who teach the big class need the tools that can accommodate a lot of audiences. To solve it, the lecturers should have an account in the tools or it is not free. The other tools can accommodate the big audience but the quality of virtual communication is not good. Finally, it will cause the quality of the learning process.

One of the categorize of the data is discrete data. It means that the data is not the continue data or independence data from the time factors. For example, is the number of students in the class. Different from the continuous data, it can not easily be measured with time, for example, the cell furcation of the amoeba. However, both of them are described by the nominal

\section{FINDING AND DISCUSSION}

In the interview process, some obstacles are to be faced by the students and the lecturers in the online learning program. Overall, almost of the respondents (the students and the lecturers) have the opinion that the learning process with face to face method is more effective than the online learning because it facilitates the students and the lectures to discuss the lessons directly. The obstacles to online learning are :

1. The limitation of information about online learning tools.

Not every lecturer and the students understand the usage of the tools. It always happens in the elderly lecturers. Most of them difficult to understand the usage or the technical way of the tools. The others, it can from the students. It always happens in students with low economic factors.

2. Not supported facilitate

Almost online learning tools need to be installed on a various electronic device. Sometimes the tools need an electronic device with a certain spec, and it is expensive. Similar to the obstacles in number one, it always comes from the students with low economic factors. They can not buy the device that supported the tools installation. Although it has little probability, it not impossible some lecturers also can not buy 
the device. Various life necessities that are not compensated with the salary, always push the lecturers to satisfy the life necessities first. The lecturers prefer to use the campus facilities although it is supported or not with the online learning tools.

3. Limitation of internet access

Stopped the learning process as an effect of the pandemic for three months cause some students and the lecturers back to their hometown. Some reasons like save the cost of living, their parents lose their job and so on be the factors. However, the learning process should be continued. The solution is the usage of online learning tools and the support of the internet. Various topography in Indonesia causes development uneven yet. It always happened in the highland areas. Then the effect is the difficulties of internet access for the students and the lecturers living in there. Besides that, students whom their parents lost the job as an effect of the pandemic also can not buy the quota for the internet.

4. Not ready budget

As meant in the obstacles in number 3, internet access needs to support online learning, and it will depend on the quota buying. The decreased income of both of the parents of the students of the institution (campus) makes it difficult to do. The pandemic makes the peoples stay at home, some of them can not go to work and it makes the decrease in income. For some institutions, the income comes from the tuition fee of the students, so it will decrease too. Some project of the institution also obstructed, so it also can be a factor of the decrease income of the institution

The obstacles found in the paper is matched with the theory put forward by Aji (2002). However, pandemic covid-19 has an incredible effect on almost part of human life. It includes healthy, salary, or income until education in all of the world. School and campus are a potential place to be a new cluster of covid-19 dissemination.

Based on the interview result, almost the respondents choose to zoom as a tool for supporting online learning. Zoom is effective because it has complete features that support to do virtual communication, chat, record, and easy access. Besides that, the zoom is easily installed not only on a laptop or computer but on a smartphone too. It is provided in the play store.

Zoom's visualization is good enough for communication or displays some presentations. Zoom is available in two option access, they are in web or application. It also saves quota for the internet. It can accommodate pretty much the audience. But it has some disadvantages like it is just can be used for 40 minutes for free except the users has an account (not free) and easy to hack.

The second favorite media from the respondents is google classroom. Some advantages are easy to use. Very save quota of the internet. It provides some features for giving announcements (usually from the lecturers), lessons, and accepting the assignment. It also connected with the user's email, so if there is a new announcement, users will be known soon. The disadvantage is it has no virtual communication features. It makes the students can not communicate with the lecturers directly. 
Finally, mix the usage between zoom and google classroom can be a solution in the online learning process. Virtual communication can be done by zoom and google classroom as a medium to collect the assignment. However, some faculty that has practiced in the laboratory can not use the online learning tools totality. Some lecturers and the students should do it face to face, but it can be anticipated by arranging the number of peoples involved in the practice activities

\section{CONCLUSION AND FURTHER RESEARCH}

Covid-19 spreading almost all over the world changes human life including in Indonesia. PSBB regulation publishes by the government makes the learning process in University stopped and changed by online learning. To support that, some tools or media are needed. The media should provide some features like virtual communications, giving the lessons, and accepting the assignment. There are several media supporting online learning like Zoom, Google Meet, Google Classroom, WAG, and Email. Almost all of the respondents choose to zoom as an effective medium. It has complete features and easy access to various electronic devices. Nevertheless, it also has some disadvantages like it is not free and easy to hack

\section{REFERENCES}

Aji, Rizqon Halal Syah. 2020. 'Dampak Covid-19 pada Pendidikan di Indonesia : Sekolah, Keterampilan dan Proses Pembelajaran'. Jurnal Sosial dan Budaya Syar-i UIN Syarif Hidayatullah Jakarta

Keputusan Presiden Republik Indonesia Nomor 12 Tahun 2020 Tentang Penetapan Bencana Nonalam Penyebaran Corona Virus Disease 2019 (Covid-19) Sebagai Bencana Nasional

'Penyelenggaraan Pembelajaran Semester Gasal 2020/2021 di Perguruan Tinggi Edisi 1 Juni 2020. Direktorat Pembelajaran dan Kemahasiswaan' Direktorat Jenderal Pendidikan Tinggi Kementerian Pendidikan dan Kebudayaan Republik Indonesia

Rawan, Prasetya dan Sri Enny Widiastuti. Pengantar Metode Penelitian. Universitas Terbuka

Susilawati, Luh Kadek Pande Ari., Supriyadi, Putu Nugrahaeni Widiasavitri, David Hizkia Tobing, Dewi Putu Astiti, I Made Rustika, Komang Rahayu Indrawati, Adijanti Marheni, Yohanes Kartika Herdiyanto, Naomi Vembriati, Luh Made Karisma Sukmayati Suarya, Made Diah Lestari, Ni Made Swasti Wulanyani, Ni Made Ari Wilani dan Putu Wulan Budisetyani. 2017. Teori dan Konsep Dasar Statistika dan Lanjut. Fakultas Psikologi Universitas Udayana 